\title{
Communication policies of Spanish universities targeting prospective students: an evaluation by secondary schools
}

\author{
Marta Barandiaran Galdós \\ Miren Barrenetxea Ayesta \\ Antonio Cardona Rodríguez \\ Ana Mar Martín Arroyuelos \\ Juan José Mijangos del Campo \\ Jon Olaskoaga Larrauri
}

Abstract: This paper presents an evaluation of the communication policies through which Spanish universities help to facilitate young people's passage from secondary to higher education. The underlying data have been gathered through a survey conducted with guidance providers at a sample of Spanish secondary schools, as well as through a series of in-depth interviews involving these same teachers. The research has led to the conclusion that the career guidance tendered by secondary schools is provided within a setting of relative precariousness in terms of information: the teachers surveyed consider that the importance of the briefing content they receive always exceeds the quality of the manner in which this information is forthcoming. The developments in the design of new university qualifications and the criteria applied by Spain's National Agency for Quality Assessment and Accreditation (ANECA) constitute a magnificent opportunity for improvement in this field.

Key words: Communication policies. Higher education institutions.

\section{Políticas de comunicação de universidades espanholas visando os futuros alunos: uma avaliação pelas escolas secundárias}

Resumo: Este artigo apresenta uma avaliação das políticas de comunicação através do qual as universidades espanholas ajudam a facilitar a passagem dos jovens do secundário para o ensino superior. Os dados subjacentes foram recolhidos através de uma pesquisa realizada com os prestadores de orientação em uma amostra de escolas secundárias espanholas, bem como através de uma série de entrevistas em profundidade envolvendo esses mesmos professores. A investigação levou à conclusão de que a orientação de carreira oferecidas pelas escolas secundárias é fornecido dentro de um cenário de precariedade relativa em termos de informações: os professores inquiridos consideram que a importância do conteúdo instrução que recebem sempre excede a qualidade da maneira pela qual esta informação está próxima. Os desenvolvimentos na concepção de novos diplomas universitários e os critérios aplicados pela Agência Nacional da Espanha de Avaliação da Qualidade e Acreditação (ANECA) constituem uma magnífica oportunidade para melhorias neste campo.

Palavras-chave: Políticas de comunicação, Instituições de ensino superior. 


\section{Introduction}

The nature, structure and importance of the communication policies that Spanish universities use when addressing prospective students can be understood only when these policies are interpreted as part of a broader and more complex mechanism: the guidance young people receive when passing from secondary to higher education.

Those of us who have studied at university know that the transition from school to university or college is difficult and challenging, albeit ultimately rewarding. The clearest proof of this is the rate of first-year drop-outs in higher education, even in the most advanced and best funded university systems (GUERRA; RUEDA, 2005; RAUSCH; HAMILTON, 2006), and the means that certain universities are employing to unravel the reasons for this phenomenon (BRINKWORTH; MCCANN; NORDSTRÖM, 2008; EMBO, 2006; RAUSCH; HAMILTON, 2006) and reduce its impact (PEAT; DALZIEL; GRANT, 2000; TAYLOR, 2008).

A large slice of the literature on this matter, including that mentioned in the preceding paragraph, has detected or proven the relationship between early leaving amongst undergraduates and the scant guidance students have received (WILLCOXSON, 2010), which is the best justification for the development of a holistic guidance system that is set in motion even before a young person goes to university in order to develop a general competence: the ability to decide upon an academic or professional career (GONZÁLEZ, 2009). In fact, the bulk of drop-outs occur amongst undergraduates who had unrealistic expectations about work and life at university that would not be later fulfilled (EMBO, 2006; RAUSCH; HAMILTON, 2006), or they made up their mind on which course to study excessively influenced by family and friends, instead of reaching a mature decision based on their own interests, skills and possibilities (GUERRA; RUEDA, 2005; RAUSCH; HAMILTON, 2006). It is at this point that universities' communication policy has a vital role to play, helping university entrants to form a sound and measured opinion not only on what university can do for them, but also on the sacrifices they will have to make before they graduate, thereby helping them to reach a decision on their academic and professional future that is conscious, rational and mature (GONZÁLEZ, 2009).

\section{Background to the research and its objectives}

In Spain, scholarly interest in guidance for university entrants is a recent phenomenon, although it has informed a body of literature that is growing rapidly. The issue has been addressed from different perspectives. Certain 
papers on the topic have delved into an explanation of the guidance role and a description of the doctrinal options in the field of guidance (RODRÍGUEZ; ÁLVAREZ; ECHEVERRÍA; MARÍN, 1993; RODRÍGUEZ, 1997); others have sought to describe the functions and structures of university guidance services (ECHEVERRÍA, 1997; SALMERÓN, 2001; SÁNCHEZ; GUILLAMÓN, 2008; VIDAL; DÍEZ; VIEIRA, 2001); finally, other authors have focused on an evaluation of these services, either by providing specific assessment criteria (VIEIRA, 2008) or by gathering opinions on university guidance services (SÁNCHEZ, 1998).

The research whose results are summarised in this paper embarks upon a two-pronged line of approach: a) its aim is to assess, yet the evaluation is based on a highly specific aspect of the part universities play in providing guidance, namely, the communication policy targeting prospective students in order to facilitate the transition from secondary to higher education; and b) this assessment is based on the opinions of one of the groups affected by this policy: the body of guidance providers or counselling teachers working at Spanish secondary schools.

This approach is explained by the fact that in Spain, the onus for providing guidance on the passage to university does not basically fall upon institutions of higher education, but instead on the schools themselves. There are various reasons for this situation, yet a prime conditioning factor is that, generally speaking, university guidance in Spain is relatively underdeveloped when compared to all the echelons of education (VIDAL et al., 2001). It is likely that, in the future, the creation of the European Higher Education Area will help to develop guidance in higher education, and it may already be doing so. Nevertheless, the current reality of guidance in Spain means that pupils in secondary education receive the bulk of the information and guidance they require at the schools where they are studying (GUERRA; RUEDA, 2005). However, these schools need to draw upon a wide range of information in order to perform this task, and as we have been able to verify during the course of this research, most of this information comes directly from the universities. This is the point that reveals the transcendence of universities' communication policy: the part they play in the passage of prospective students involves providing the briefing material and the structural support to enable secondary schools to effectively undertake their advisory role.

\section{Research design and methods}

The data used to achieve the paper's aims have been gathered directly from those schools that teach subjects leading to university entrance. This field work 
has involved two complementary instruments, a questionnaire and a personal interview, which have been applied to those teachers responsible for providing guidance.

The exploratory nature of the research means there is no ready-made questionnaire applicable to this case that has been endorsed by previous research. This has therefore required the preparation of an ad hoc questionnaire whose design and content is the result of merging several sources. The main one is to be found within the legal context: Spain's Royal Decree 1393/2007, regulating official studies in higher education, which lays down that once the curricula have been drawn up, they are to be verified, and for this purpose Spain's National Agency for Quality Assessment and Accreditation (ANECA) has introduced a number of protocols based on a series of criteria, some of which specify the information that Spanish universities are to provide to their present and future students. Apart from the legal precepts, the questionnaire's final design is indebted to the researchers' expertise and background in the field of communication policy, backed by the opinions of an array of experts in teaching and guidance that were called upon to validate the draft.

The main body of the questionnaire, in its definitive version, asks respondents to use a scale ranging from "very low" to "very high" to rate the importance of thirty briefing items classified into six blocks.

The rest of the questionnaire requires the respondent to indicate the main source of the information on these briefing items, list the channels commonly used accordingly, select the three deemed to be most effective and name the university that is considered to stand out from the rest in terms of communication policy. The questionnaire also includes several questions for identifying the respondent.

The questionnaire was circulated between November 2008 and May 2009 via the internet, with this being the option of choice given its low cost, the speed in which the results were forthcoming and the facilities of the platform used regarding the tabulation of data. Use was made of a motivational letter, sent by e-mail, from where a link provided access to the questionnaire.

The sample used consisted of 876 schools chosen from a database of 5,089 schools and colleges teaching formal secondary education (Bachillerato), upper level occupational training (Formación Profesional de grado superior), plastic arts and design (Artes Plásticas y Diseño) y and sports education (Enseñanzas Deportivas). The database was built up by combining the information on schools and colleges from each one of Spain's regions, the Autonomous Communities. The sampling size chosen was the outcome of a series of decisions: firstly, a 
goal was set of a 95\% confidence level with an error margin of no more than $5 \%$, which meant the sample could not have fewer than 358 schools. Nonetheless, the decision was taken to double the sample size in order to compensate for a foreseeably high rate of non-responses. Finally, the sample was extended to include 876 schools so that certain Autonomous Communities would be properly represented.

In the end, the number of answers in the field work amounted to 275 . The high rate of non-responses means that no claim can be made for statistical accuracy in the strictest sense. Nonetheless, the number of answers is sufficiently high for serious consideration to be given to the data gathered.

In addition to the questionnaire, the research used a complementary instrument: a personal interview with the teachers in 142 secondary schools, with 82 of these being face-to-face and the remainder held over the phone. The purpose of these interviews was to collect the views and opinions of the guidance providers working at the schools, single out the most important items on their agenda and identify the underlying discourses at the schools. Accordingly, the sample's representativeness was not considered significant for this part of the field work.

Ultimately, the information gathered through these two methods, questionnaire and interview, proved to be fully compatible.

\section{Evaluation of university communication policies from the perspective of secondary schools}

Secondary schools are the preferred target for the briefing policies that universities use for facilitating the transition from secondary to higher education, as confirmed by prior research both into the design and operation of university services (SÁNCHEZ; GUILLAMÓN, 2008) and into the passage to higher education (GUERRA; RUEDA, 2005). Accordingly, the opinion secondary schools have on the quality and pertinence of the information they receive from universities is deemed to be essential.

This section gathers the opinions of guidance providers in secondary education regarding the usual content of universities' communications policies and on the quality of the manner in which that information is conveyed. The section likewise reports on the channels through which the guidance providers receive the information they require, and its serves to qualify their preferences on this matter.

The interest of the results presented under this heading is twofold. On the one hand, the information it contains allows a diagnosis to be made of the communication policies rolled out by Spanish universities; on the other, it may 
be of use to those universities seeking to adapt the content of their policies and the instruments they use in their application to the needs and preferences of their target audiences.

\subsection{Perception of the relative importance to prospective students of universities' communication policy}

The first conclusion that can be drawn from the answers provided by guidance providers on the relative importance of the briefing content is that there is an order of priority that ultimately places certain issues above others in terms of their importance to pupils. Those items linked to the offer of available courses are, for the guidance providers in the survey, the ones of greatest importance to their pupils. In the ranking based on the relative frequencies of "high" and "very high" responses (table I), these items appear on five occasions in the top ten positions and receive an average evaluation that is clearly higher than the other categories. On a second level of importance there is the information on the availability of mechanisms for helping graduates to find a job. In third place, secondary schools rate the information on results, although within this category the items given the greatest importance involve the job potential of each degree course, clearly of greater importance than academic results. The categories teaching-learning process and student induction generally receive a similar evaluation from the guidance providers. Nonetheless, in both these categories the aspects that stand out from all the other briefing items are those related to the openings universities provide for studying abroad or for undertaking job placements. This issue will be addressed again in due course. Well below all the other categories are "personal and welfare services", to which only a minority of schools rate with a "high" or "very high" response.

The range of courses on offer is, as noted earlier, the star category, at least from the standpoint of the guidance providers and heads of study surveyed. With the exception of information on lecture timetables, all the other briefing content in this category is deemed to be important by a majority of those surveyed and is ranked in the top ten of content. This does not mean there are no differences between the briefing items that make up this category. In general, it may be affirmed that, according to those surveyed, the conditions of access to undergraduate courses and the actual range of courses available are the sine qua non data that all universities should provide. This concern for the content of each university course (syllabus, nature, focus and difficulty of the subjects) is understandable amongst those responsible for providing guidance in secondary schools, for as we have learnt through personal interviews, most of 
the queries they receive from pupils and their parents refer precisely to such matters. Meanwhile, the entrance requirements (advised subjects of study) and graduation prospects (what the degree can be used for) are slightly down the list in the order of preference for those surveyed. The personal interviews held with the guidance providers suggest they are not familiar with these concepts at secondary schools, or with the design of competency-based teaching.

The extent to which higher education opens the doors to employment for graduates is, for those surveyed, the second briefing item in order of importance. This finding coincides with the opinions expressed by the guidance providers and heads of study interviewed personally, who agree in pointing out that both pupils and their parents are concerned about the openings provided by degree courses. According to these data, pupils are more interested in finding out about the mechanisms the university will use in the future to help them find a job than those used to monitor its graduates.

The importance given to the briefing items on the teaching-learning process also follows a pattern: greater importance is given to those aspects peripheral to new teaching methodologies than to the actual methods themselves. The possibility of studying abroad and job placements are accessory considerations in the methodological overhaul that is taking place in Spanish higher education. From this it is deduced that, if they are valued, it is more because they generate immediate possibilities that are attractive to prospective students, associated either with their academic experience or with their access to the labour market, than for the role they play in the actual learning process.

All the briefing content on student induction is considered important by around half of the schools surveyed. This category does not record significant differences between the various induction mechanisms, although it may be of interest to note that the schools consider the information on the existence and operations of the university guidance service (Servicio de Orientación Universitaria) to be more important than any other in this category ( $59 \%$ of those surveyed coincide in stating that this information is important or very important), probably because the guidance providers at secondary schools perceive that the counselling services at universities are a good interlocutor for their inquiries, as revealed by the interviews held with these teachers.

Finally, the guidance providers in secondary education coincide in showing relatively little interest in the information on a university's approach to personal and welfare services. Within this category, more importance is given to the information on sports, cultural and leisure facilities than anything else, including psycho-pedagogic services or student associations. 


\section{Table I - Opinion of secondary schools on the relative importance of briefing content}

\begin{tabular}{|c|c|c|c|}
\hline Category and briefing item & $\begin{array}{l}\text { Frequency of } \\
\text { answers for "high" } \\
\text { and "very high" }\end{array}$ & Mean* & $\begin{array}{l}\text { Ranking of } \\
\text { perceived } \\
\text { importance** }\end{array}$ \\
\hline \multicolumn{4}{|l|}{ INFORMATION ON DEGREE COURSES } \\
\hline Offer of degree courses (specialities, curricula, syllabuses...) & $84 \%$ & 4.2 & 2 \\
\hline $\begin{array}{l}\text { Number of places available, past entry requirements, present entry } \\
\text { requirements... }\end{array}$ & $85 \%$ & 4.3 & 1 \\
\hline $\begin{array}{l}\text { Prior studies recommended (type of secondary education, mastery of } \\
\text { certain subjects...) }\end{array}$ & $77 \%$ & 4.0 & 3 \\
\hline The openings provided by the degree course & $76 \%$ & 4.0 & 4 \\
\hline Information on grants, transport and accommodation & $60 \%$ & 3.6 & 10 \\
\hline Mean evaluation of the briefing items regarding degree courses & $67 \%$ & 3.8 & \\
\hline $\begin{array}{l}\text { Counsellor-lecturer at the university who advises on the course and } \\
\text { learning methods }\end{array}$ & $48 \%$ & 3.3 & 17 \\
\hline Student-tutor programme for helping to integrate at university & $44 \%$ & 3.2 & 23 \\
\hline University counselling service & $59 \%$ & 3.5 & 12 \\
\hline Mean evaluation of the briefing items regarding student induction & $49 \%$ & 3.3 & \\
\hline \multicolumn{4}{|l|}{ INFORMATION ON THE TEACHING-LEARNING PROCESS } \\
\hline Competences to be acquired by course and subject & $44 \%$ & 3.2 & 22 \\
\hline Teaching methods used, size of groups and assessment processes & $48 \%$ & 3.3 & 16 \\
\hline $\begin{array}{l}\text { Option of pursuing part of the degree course at university abroad } \\
\text { Mean evaluation of the briefing items regarding the teaching-learning } \\
\text { process }\end{array}$ & $62 \%$ & 3.6 & 8 \\
\hline \multicolumn{4}{|l|}{ INFORMATION ON PERSONAL-WELFARE SERVICES } \\
\hline Facilities for sport, culture, leisure and cultural development & $28 \%$ & 3.0 & 26 \\
\hline Student associations & $14 \%$ & 2.6 & 29 \\
\hline Former students association & $6 \%$ & 2.1 & 30 \\
\hline Psycho-pedagogic counselling & $24 \%$ & 2.7 & 27 \\
\hline $\begin{array}{l}\text { Mean evaluation of the briefing items regarding personal and welfare } \\
\text { services }\end{array}$ & $18 \%$ & 2.6 & \\
\hline \multicolumn{4}{|l|}{ INFORMATION ON SERVICES FOR HELPING WITH JOB FINDING } \\
\hline Advertising job vacancies & $71 \%$ & 3.8 & 5 \\
\hline Career guidance & $66 \%$ & 3.7 & 6 \\
\hline $\begin{array}{l}\text { Monitoring job finding (type of positions, type of companies, salaries, } \\
\text { geographic location...) }\end{array}$ & $51 \%$ & 3.4 & 13 \\
\hline Mean evaluation of the briefing items regarding job finding & $63 \%$ & 3.6 & \\
\hline \multicolumn{4}{|l|}{ INFORMATION ON RESULTS } \\
\hline First-year failure & $46 \%$ & 3.3 & 19 \\
\hline $\begin{array}{l}\text { Drop-outs, graduation, students graduating within the established } \\
\text { timeframe... }\end{array}$ & $37 \%$ & 3.1 & 25 \\
\hline
\end{tabular}

* Mean for the answers when restated in quantitative terms ("very low" = 1; "low" = 2, "average" = 3, "high" = 4, "very high alto" = 5).

** Ordered by frequency in terms of the answers "high" and "very high"

Source: Compiled by author. 


\subsection{Perception of the quality of universities' communication policy regarding prospective students}

The part they play as the interface mechanism in the communication process between universities and their prospective students places secondary schools in an advantageous position to evaluate the appropriateness of the briefing content universities provide, the efficacy of the means they employ and, in general, the quality of the communication process.

Indeed, it would not be too bold to affirm that guidance providers at secondary schools are more aware than universities themselves of the interests, concerns and difficulties their pupils face when deciding upon their academic future. This standpoint contains, nonetheless, a major speculative ingredient, which is the reason that the instigators of this research have opted for requesting those responsible for guidance at secondary schools to make an explicit assessment of the quality of the information they receive from universities and which they use during the course of their duties.

Table II shows the content of the communication policies whose quality has been rated as "high" or "very high" by a greater number of schools. Standing out from all the other contents that have traditionally occupied the channels of communication between universities and secondary schools are "offer of degree courses" and "terms of access", for which the current briefing mechanisms appear to satisfy the majority of secondary schools. This group also features the content on universities' technical facilities and communal areas.

These data reveal, in short, that there are certain aspects of universities' communication policy with which the schools are reasonably satisfied; however, and given that the schools are being asked to carry out an evaluation exercise, it is perhaps more interesting to focus on the content regarding which the schools affirm they do not receive quality information.

Those surveyed stress the almost non-existent quality of the information on academic results and access to the labour market. For example, the quality of the information on drop-out rates, graduation or the average time each student takes to complete the degree course is rated as "low" or "very low" by $81 \%$ of the schools questioned ${ }^{1}$. The feeling that Spanish universities are not particularly concerned about informing prospective students on these matters is readily

1 The authors of this paper have also surveyed those responsible for communication policy at universities, with the slightly worrying finding that they show less interest than schools for certain briefing content, amongst others regarding precisely those associated with the outcomes of university students in the academic and professional fields. In these circumstances, the idea should not be dismissed that part of the problem reflected by the data is due to the different approaches between these two echelons of education and, in the final instance, to the shortcomings of the channels of communication and of the mechanisms of coordination that have been established between them. 
apparent when analysing their websites. The cases in which comprehensive information is provided on these issues are few and far between and, furthermore, the universities that do provide such data rarely do so through the links designed for prospective students.

The guidance providers are also critical about the information on the teaching methods used at universities, and about the provision of personal and welfare services. Nonetheless, it should be remembered that this information was not considered overly important by the schools, which tempers the seriousness of its scant quality.

Indeed, the relationship between the importance attributed and the quality perceived may be a good measure of the precariousness of the information with which guidance providers at secondary schools undertake their duties. This precariousness is all the greater the higher the importance of a specific issue and the lower the quality of the information they have on it. Graph I provides an initial appreciation of the precariousness of this information: there is not a single briefing item in which the schools consider there is an excess of information; or to put it another way, schools give a far higher rating to the importance of any one of the items than to the quality of the information they have on it.

\section{Graph I - Importance given to briefing content vs. perceived quality}

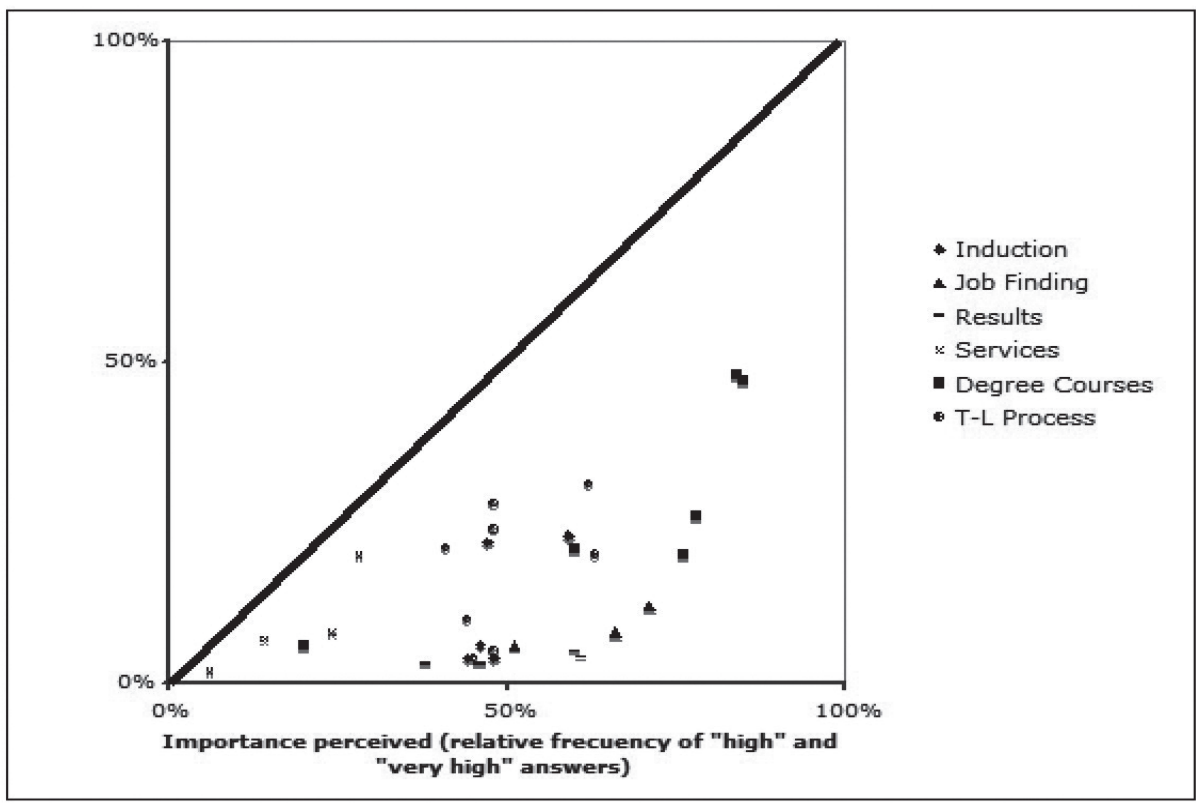

Source: Compiled by author. 


\section{Table II - Opinion of secondary schools on the quality of the information received by briefing item}

\begin{tabular}{|c|c|c|c|}
\hline Category & $\begin{array}{l}\text { Frequency of an- } \\
\text { swers for "high" } \\
\text { and "very high" }\end{array}$ & Mean $^{*}$ & $\begin{array}{l}\text { Ranking of } \\
\text { perceived } \\
\text { quality** }\end{array}$ \\
\hline \multicolumn{4}{|l|}{ INFORMATION ON DEGREE COURSES } \\
\hline Offer of degree courses (specialities, curricula, syllabuses...) & $48 \%$ & 3.3 & 1 \\
\hline $\begin{array}{l}\text { Number of places available, past entry requirements, present entry require- } \\
\text { ments... }\end{array}$ & $47 \%$ & 3.3 & 2 \\
\hline $\begin{array}{l}\text { Prior studies recommended (type of secondary education, mastery of certain } \\
\text { subjects...) }\end{array}$ & $26 \%$ & 2.7 & 5 \\
\hline Information on grants, transport and accommodation & $21 \%$ & 2.7 & 9 \\
\hline The openings provided by the degree course & $20 \%$ & 2.7 & 13 \\
\hline Lecture timetable & $6 \%$ & 1.9 & 21 \\
\hline Mean evaluation of the briefing items regarding degree courses & $28 \%$ & 2.8 & \\
\hline \multicolumn{4}{|l|}{ INFORMATION ON STUDENT INDUCTION } \\
\hline University counselling service & $23 \%$ & 2.7 & 7 \\
\hline Induction sessions for first-year undergraduates & $22 \%$ & 2.7 & 8 \\
\hline Support programme for first-year undergraduates & $6 \%$ & 2.2 & 20 \\
\hline Student-tutor programme for helping to integrate at university & $4 \%$ & 2.0 & 24 \\
\hline $\begin{array}{l}\text { Counsellor-lecturer at the university who advises on the course and learning } \\
\text { methods }\end{array}$ & $4 \%$ & 2.0 & 27 \\
\hline Mean evaluation of the briefing items regarding student induction & $12 \%$ & 2.3 & \\
\hline \multicolumn{4}{|l|}{ INFORMATION ON THE TEACHING-LEARNING PROCESS } \\
\hline Option of pursuing part of the degree course at university abroad & $31 \%$ & 3.0 & 3 \\
\hline $\begin{array}{l}\text { Communal areas and facilities: laboratories, workshops, libraries and study } \\
\text { rooms }\end{array}$ & $28 \%$ & 2.8 & 4 \\
\hline Computer rooms for use by students & $24 \%$ & 2.7 & 6 \\
\hline Multimedia infrastructure in lecture rooms & $21 \%$ & 2.6 & 10 \\
\hline Outside placements & $20 \%$ & 2.6 & 11 \\
\hline Competences to be acquired by course and subject & $10 \%$ & 2.2 & 15 \\
\hline Teaching methods used, size of groups and assessment processes & $5 \%$ & 2.0 & 23 \\
\hline Monitoring of each student's learning process & $4 \%$ & 2.0 & 25 \\
\hline Mean evaluation of the briefing items regarding the teaching-learning process & $18 \%$ & 2.5 & \\
\hline \multicolumn{4}{|l|}{ INFORMATION ON PERSONAL-WELFARE SERVICES } \\
\hline Facilities for sport, culture, leisure and cultural development & $20 \%$ & 2.6 & 12 \\
\hline Psycho-pedagogic counselling & $8 \%$ & 2.0 & 17 \\
\hline Student associations & $7 \%$ & 2.1 & 18 \\
\hline Former students association & $2 \%$ & 1.8 & 30 \\
\hline $\begin{array}{l}\text { Mean evaluation of the briefing items regarding personal and welfare } \\
\text { services }\end{array}$ & $9 \%$ & 2.1 & \\
\hline \multicolumn{4}{|l|}{ INFORMATION ON SERVICES FOR HELPING WITH JOB FINDING } \\
\hline Advertising job vacancies & $12 \%$ & 2.4 & 14 \\
\hline Career guidance & $8 \%$ & 2.3 & 16 \\
\hline $\begin{array}{l}\text { Monitoring job finding (type of positions, type of companies, salaries, geo- } \\
\text { graphic location...) }\end{array}$ & $6 \%$ & 2.1 & 19 \\
\hline Mean evaluation of the briefing items regarding job finding & $9 \%$ & 2.3 & \\
\hline \multicolumn{4}{|l|}{ INFORMATION ON RESULTS } \\
\hline Matching between the job and the degree course & $5 \%$ & 2.0 & 22 \\
\hline Time taken to find a job & $4 \%$ & 2.0 & 26 \\
\hline First-year failure & $3 \%$ & 1.8 & 28 \\
\hline $\begin{array}{l}\text { Drop-outs, graduation, students graduating within the established time- } \\
\text { frame... }\end{array}$ & $3 \%$ & 1.8 & 29 \\
\hline Mean evaluation of the briefing items regarding results & $4 \%$ & 1.9 & \\
\hline
\end{tabular}

* Mean for the answers when restated in quantitative terms ("very low" = 1; "low" = 2, "average" = 3, "high" = 4, "very high" = 5).

** Ordered by frequency in terms of the answers "high" and "very high".

Source: Compiled by author. 


\section{Conclusions}

A large part of the evaluation of universities' communication policy presented in this paper is based on the answers provided by school counsellors in the questionnaires they were asked to complete. Yet beyond the actual content of these answers, the emphatic nature, manner and feeling of the opinions they give reveals a markedly critical viewpoint.

Most of the school counsellors surveyed have said that, generally speaking, they are not satisfied with the information and support they receive from their reference universities. These guidance providers complain that they are forced to track down basic information on access and syllabuses for each individual university, and then compile it in a way that provides their pupils with a comprehensive understanding of their options; in their view, the content of the different degree courses is expressed in a way that the pupils find hard to understand, and the teachers themselves admit they also find it somewhat obtuse; they express the challenges they face when dealing with the chaotic structure of certain university websites; they are disgruntled by the fact that a fair proportion of the information they receive by post is of little use for providing serious guidance.

The obviously critical tone with which secondary schools evaluate the briefing policies of Spanish universities is yet another facet of the scant communication that has traditionally existed between these echelons of education (GUERRA; RUEDA, 2005), and which has been confirmed by the answers provided when schools have been asked about the degree of coordination between schools preparing for university entrance and the universities themselves. 63\% of those surveyed declared that the coordination is low or very low, whereas only $8 \%$ considered it to be high or very high. Meanwhile, the universities themselves see things quite differently; that is, most university guidance services seem to be unaware of the problems of coordination between these two echelons of Spain's education system.

The negative feedback forthcoming in the personal interviews held with the guidance providers in secondary education has been confirmed by their answers to the questions they have been asked regarding the quality of certain aspects of the briefing content they receive. The survey was based on $30 \mathrm{di}-$ fferent content items, ranging from the information on a university's offer of degree courses or the number of places available and entry grades required, through to the information on the university's facilities regarding computer rooms, psycho-pedagogical support, or the advertising of job vacancies. The results were extremely revealing: in each and every one of the briefing items 
the group of secondary-school guidance providers gave a higher rating to the importance of the information on the item in question than to the quality with which it is received. The diagnosis is clear and should be stated emphatically: the guidance providers at the schools surveyed are dissatisfied with universities' communication policy and they are forced to undertake their counselling role facing a lack of information that can only compromise the effectiveness of their task.

There are in all probability numerous reasons for this situation, and their solution requires Spanish universities to become mindful of the importance of these policies and allocate more means for their implementation, furnish them with more appropriate structures or fine-tune the operations of those already in place. Nevertheless, there is something that the research summarised in this paper can do to improve the situation. The dissatisfaction schools manifest regarding the information supplied may be due in part to the fact that universities and schools differ in the way they look upon the briefing priorities of undergraduates about to embark upon a degree course. If this is true - and the answers provided by the questionnaires submitted to universities and schools seem to ratify it - the first thing institutions of higher education should do is introduce mechanisms of dialogue with secondary education, and thereby ensure that their efforts are focused on those matters that the recipients of their policies deem to be most important.

In short, the evaluation of the communication between universities and secondary schools with a view to paving the way for young people as they pass from one echelon to another shows that there are still aspects that need to be improved. It is likely that these shortcomings are no more than the local reflection of a more general problem in the scant coordination between these two echelons of education. If this is true, we should welcome the proposals of the European Higher Education Area in the way it will lend consistency to the education process, from the initial stages in people's lives and throughout their entire lifetimes. 


\section{References}

BRINKWORTH, Russel; MCCANN, Bem; NORDSTRÖM, Karin. First year expectations and experience: student and teacher perspectives. Higher Education, Netherlands, v. 58, p. 157-173, 2008.

ECHEVERRÍA, Benito Samanés. Los servicios universitarios de orientación. In APODACA, Pedro; LOBATO, Clemente. (Eds.). Calidad en la Universidad: orientación y evaluación. Barcelona: Laertes, 1997.

EMBO. From School to University - a report on the transition from secundary school biology education to university in Europe, 2006. Available in: $<$ http://www.embo.org/documents/report.pdf $>$. Access: june 22, 2012.

GONZÁLEZ, Viviana Maura. Autodeterminación y conducta exploratoria. Elementos esenciales en la competencia para la elección profesional responsable. Revista Iberoamericana de Educación, Madrid, v. 51, p. 201220, 2009.

GUERRA, Carlos Rodríguez; RUEDA, Eva M. Domínguez. Estudio longitudinal de los jóvenes en el tránsito de la enseñanza secundaria a la universidad: orientación, expectativas, toma de decisiones y acogida de los nuevos estudiantes en la universidad. Informe para el Programa de Estudios y Análisis del Ministerio de Educación y Ciencia (convocatoria 2005) de la Secretaría de Estado de Universidades e Investigación, 2005. Available in: $<$ http://www.mec.es/univ/proyectos2005/EA2005-0266.pdf.>. Access: june $22,2012$.

PEAT, Mary; DALZIEL, James; GRANT, Anthony M. Enhancing the transition to university by facilitating social and study networks: results of a One-day Workshop. Innovations in Education and Training International, New York, v. 37, n. 4, p. 293-303, 2000.

RAUSCH, John L.; HAMILTON, Matthew W. Goals and distractions: explanations of early attrition from traditional university freshmen". The Qualitative Report, Flórida, v. 11, n. 2, p. 317-334, June, 2006

RODRÍGUEZ, Sebastián Espinar. Orientación universitaria y evaluación de la calidad. In APODACA, Pedro \& LOBATO, Clemente. (Eds.). Calidad en la Universidad: orientación y evaluación. Barcelona: Laertes, 1997. 
RODRÍGUEZ, Sebastián Espinar; ÁLVAREZ, Manuel; ECHEVERRÍA, Benito; MARÍN, María A. Teoría y práctica en la orientación educativa. Barcelona: PPU, 1993

SALMERÓN, Honorio Pérez. Los servicios de orientación en la Universidad. Procesos de creación y desarrollo. Ágora Digital, Valladolid, n. 2, 2001. Available in: <http://www.uhu.es/agora/version01/digital/ numeros/02/02articulos/monografico/salmeron.PDF>. Access: june 22, 2012.

SÁNCHEZ, María F. García. Las funciones y necesidades de orientación en la Universidad: un estudio comparativo sobre las opiniones de universitarios y profesionales. Revista de Orientación Psicopedagógica, Madrid, v. 9, n. 5, p. 87-107, 1998.

SÁNCHEZ, María F. García; GUILLAMÓN, José R. Fernández. (Coords.). Situación actual de los servicios de orientación universitaria: estudio descriptivo. Revista de Educación, Madrid, n. 345, p. 329-352, enero-abril, 2008.

TAYLOR, Janet A. Assessment in first year university: a model to manage transition. Journal of University Teaching and Learning Practice, Wollongong, NSW, Australia, v. 5, n. 1, article 3, 2008.

VIDAL, Javier; DÍEZ, Gloria; VIEIRA, María J. La oferta de los servicios de orientación en las universidades españolas: innovación y ajuste a las necesidades de la comunidad universitaria. Informe para el Programa de Estudios y Análisis del Ministerio de Educación Cultura y Deporte (convocatoria 2001) de la Secretaría de Estado de Educación y Universidades, 2001. Available in: < http://www3.unileon.es/dp/amide/inves/ publi/Servori.pdf $>$. Access: june 22, 2012.

VIEIRA, María J. Criterios para la evaluación del sistema de apoyo y orientación al estudiante universitario: revisión y propuesta. Revista de Educación, Madrid, n. 345, p. 399-423, enero-abril, 2008.

WILLCOXSON, Lesley. Factors affecting intention to leave in the first, second and third year of university studies: a semester-bysemester investigation. Higher Education Research \& Development, Hammondville, Austrália, v. 29, n. 6, p. 623-639, 2010. 
Marta Barandiaran Galdós - Universidad del País Vasco UPV/EHU Bilbao | España. Contato: marta.barandiaran@ehu.es

Miren Barrenetxea Ayesta - Universidad del País Vasco UPV/EHU Bilbao | España. Contato: miren.barrenetxea@ehu.es

Antonio Cardona Rodríguez - Universidad del País Vasco UPV/EHU Bilbao | España. Contato: antonio.cardona@ehu.es

Ana Ma Martín Arroyuelos - Universidad del País Vasco UPV/EHU Bilbao | España. Contato: ana.martin@ehu.es Juan José Mijangos del Campo - Universidad del País Vasco UPV/EHU Bilbao | España. Contato: juanjo.mijangos@ehu.es Jon Olaskoaga Larrauri - Universidad del País Vasco UPV/EHU Bilbao | España. Contato: jon.olaskoaga@ehu.es

Artigo recebido em 7 de março de 2013 e aprovado em 20 de março de 2013. 